\title{
PERAN GURU PROFESIONAL SEBAGAI FASILITATOR DAN KOMUNIKATOR DALAM KEGIATAN BELAJAR MENGAJAR
}

\begin{abstract}
:
Oleh: Arfandi Mohamad Aso Samsudin

Email:

Arfandi.1985@gmail.com moh.asosamsudin@gmail.com

Universitas Ibrahimy Situbondo

The role of professional teachers in carrying out activities as educators obligate to have a capability in the learning plan, performing the learning activities, and evaluate learning outcomes. Professional teachers have to own competence, both personal competence, pedagogical competence, and social competence. There are several important roles for a professional teacher that are as a leader, guide, supervisor, counselor, expeditor, motivator, facilitator, and communicator. The role of the teacher as a facilitator to provide great service with the aim of providing convenience to students in teaching and learning activities, to realize teachers as facilitators, teacher needs to provide various learning resources and learning media that are relevant as well as make active learning, innovative, creative and fun. Whereas, the teacher as a communicator in teaching and learning activities that the relationship between the teacher and students is not only "top-down" but a partnership, through the partnership model the teacher will act as a guide and companion in teaching and learning activities so that created a delight and democratic learning atmosphere.
\end{abstract}

Keywords: Professional Teachers, Teaching and Learning Activities

\section{PENDAHULUAN}

Kehadiran guru dalam kegitan belajar mengajar merupakan salah satu komponen penting mengingat kehadiran guru tidak hanya sebagai pengajar akan tetapi juga berperan sebagai pendidik, pelatih, pengarah, pembimbing, penilai dan mengevaluasi. ${ }^{1}$ Guru merupakan jabatan atau profesi yang memerlukan keahlian khusus. Orang yang pandai berbicara dalam bidang-bidang tertentu, belum dapat disebut sebagai guru.Untuk menjadi guru diperlukan syarat-syarat khusus, apalagi sebagai guru yang professional harus menguasai betul seluk beluk pendidikan dan pengajaran. Tugas dan peran guru tidaklah terbatasi dalam masyarakat, bahkan guru pada hakekatnya merupakan komponen strategis yang memilih peran penting dalam menentukan gerak maju kehidupan bangsa. Bahkan selain itu, tugas dari

\footnotetext{
${ }^{1}$ Arfandi, "Pemanfaatan Media Pembelajaran dalam Meningkatkan Kualitas Pembelajaran PAI di Sekolah", Edupedia: Jurnal Studi Pendidikan dan Pedagogi Islam, Vol. 5, No. I (Juli, 2020), 70.
}

seorang guru bukan hanya berperan penting dalam mentrasfer pengetahuan saja, melainkan guru juga berperan sebagai pendidik dan juga memberikan bimbingan baik secra rohani maupun secra jasmani. ${ }^{2}$

Dalam dunia pendidikan guru mempunyai peranan yang sangat penting dalam pengembangan sumberdaya manusia melalui pendidikan. Profesi guru mempunyai tugas sebagai fasilitator dan komunikator untuk mendidik, mengajar dan melatih anak didiknya. Berkenaan dengan urgensi tugas guru professional tersebut, perlu disusun sebuah artikel yang mampu menjadi wahana bagi guru untuk memperoleh wawasan, pengetahuan, dan konsep keilmuan berkenaan dengan guru professional sebagai fasilitator dan komunikator baik secara teoritis maupun secara praktis.

\footnotetext{
${ }^{2}$ Arfandi, "Pemanfaatan Media Pembelajaran dalam Meningkatkan Kualitas Pembelajaran PAI di Sekolah", Edupedia: Jurnal Studi Pendidikan dan Pedagogi Islam, Vol. 5, No. I (Juli, 2020), 70.
} 


\section{PEMBAHASAN}

\section{Pengertian Guru Profesional}

Profesi berasal dari kata "profession" dari bahasa Inggris dan "professus" dari bahasa Latin yang artinya pekerjaan atau mata pencaharian. Menurut Undang-Undang Guru dan Dosen pasal 1 Nomer 14 tahun 2005, profesional adalah pekerjaan atau kegiatan yang dilakukan oleh seseorang dan menjadi sumber penghasilan kehidupan yang memerlukan keahlian, kemahiran, atau kecakapan yang memenuhi standar mutu atau norma tertentu serta memerlukan pendidikan profesi.

Menurut Kunandar, guru yang profesional adalah guru yang memiliki kompetensi yang dipersyaratkan untuk melakukan tugas pendidikan dan pengajaran. Kompetensi ini meliputi pengetahuan, sikap dan keterampilan profesional, baik yang bersifat pribadi, sosial, maupun akademis. ${ }^{3}$

Menurut Moh. Uzer Usman, pengertian guru profesional adalah sebuah pekerjaan yang bersifat profesional yang yang mana di dalamnya memerlukan beberapa bidang ilmu yang secara sengaja harus ditekuni dan dipelajari kemudian ilmu itu bisa diaplikasikan. Selain itu guru yang profsional harus mempunyai komptensi khusus dalam bidang keguruan sehingga ia mampu menjalankan tugas dan fungsinya sebagai guru dengan memiliki kemampuan yang maksimal. ${ }^{4}$ Dari bebrapa pengertian tentang guru professional yang dijelaskan oleh bebrapa para ahli, maka dapat disimpulakan bahwa guru yang professional adalah seorang guru yang memiliki kompetensi dan kualifikasi baik sebagai pendidik maupun sebagai pengajar dalam kegiatan belajar mengajar dengan mempunyai kemampuan di dalam perencanaan proses pembelajaran, pelaksanaan pembelajaran dan mengevaluasi hasil belajar siswa.

\section{Peran Guru dalamPembelajaran}

Sebagai guru professional dalam kegiatan belajar mengajar, seorang guru tidak hanya menjalankan tugas dan fungsinya sebagai orang yang ahli ilmu pengetahuan (transfer of knowledge)

\footnotetext{
${ }^{3}$ Kunandar, Guru Profesional Implementa I Kurikulum Tingkat Satuan Pendidikandan Sukses dalam Sertifikasi Guru. (Jakarta: Raja Grafindo Persada, 2007), 46.

${ }^{4}$ Moh. User Usma, Menjadi Guru Profesional, (Bandung: PT. Remaja Rosdakarya, 2010), 15.
}

akan tetapi juga seorang guru bisa berfungsi untuk bisa menanamkan nilai (value) serta bisa membangun karakter (character building) peserta didik secara berkelanjutan dan berkesinambungan.

Perkembangan arus globalisasi terhadap pandangan belajar rmengajar memberikan dampak yang positif bagi seorang guru guna meningkatkan kompetensi dan perannya dalam kegiatan belajar mengajar karena salah satu faktor keberhasilan siswa adalah sangat ditentukan oleh kompetensi dan peran dari seorag guru sebagai pendidik dan pengajar. Guru yang memiliki kompetensi tentu akan sangat mampu dalam menciptakan suasana pembelajaran yang menyenangkan dan kondusif, dan juga mempu mengelola kelas sehingga kegiatan belajar mengajar menjadi aktif, inovatif, kereatif dan menyenangkan sehingga semua itu akan menjadikan hasil belajar siswa sangat baik dan berkembang secara optimal.

Kompetensi dan peran penting seorang guru selain sebagai pendidik dan pengajar seorang guru juga harus bisa mempunyai beberapa peran penting dalam kegiatan belajar mengajar antara lain seperti sebagai pemimpin kelas, pembimbing, pengatur, pengatur lingkungan, partisipan, ekspeditor, perencana, supervisor, motivator dan konselor yang akan dijelaskan di sini adalah peranan yang dianggap paling dominan dan diklasifikasikan sebagai berikut:

\section{Guru Sebagai Pendidik}

Tugas dan peran guru sebagai pendidik adalah bagaimana seorang guru mampu meningkatkan dan menumbuh kembangkan potensi anak didik untuk mendapatkan pemahaman dan pengalaman dalam hidupnya seprti memiliki pengetahuan dan keterampilan, menjaga kesehatan jasmani dan rohani, mempunyai sifat mandiri, memiliki karakter yang kuat dan memiliki rasa tanggungjawab bagi dirinya masyarakat bangsa dan negara, baik yang bersifat personal (individual), sosial dan spiritual.

Dengan demikian, tugas dan peran guru sebagai pendidik dalam kegiatan belajar mengajar mempunyai tanggungjwab di dalam menjaga dan mngontrol segala aktivitas yang dilakukan dan memberikan pengarahan, bimbingan serta motivasi agar anak didik tersebut dalam segala aktivitas yg dilakukannya sesuai dengan norma yang ada dan sesuai dengan ajaran agama Islam. 


\section{Guru Sebagai Pengajar}

Ada beberapa faktor yang mempengaruhi guru sebagai pengajar dan pembimbing dalam kegiatan belajar mengajar antara lain sperti interaksi yang harmonis antara guru dan anak didik, kemampuan guru dalam bersosialisasi, rasa aman dan keterampilan guru dalam berkomunikasi..$^{5}$ Kegitan belajar mengajar akan berjalan dengan efektif dan efesien ketika seorang guru sebagai pengajar mampu memecahkan masalah dan memiliki keterampilan dasar mengajar yang baik.

Guru sebagai pengajar harus melakukan beberapa hal dalam kegiatan belajar mengajar, seperti menciptakan kondusifitas di kelas, menciptakan kepercayaan kepada pserta didik, merespon dengan baik, memberikan penguatan, mendengarkan, menyediakan media pembelajarna, menggunakan metode pembelajaran yang bervariatif. Untuk menjadikan kegiatan belajar mengajar mempunyai kekuatan yang maksimal, tentu seorang guru harus selalu berkometmen untuk meningkatkan dan juga mempertahankan semangat dalam memberikan materi pelajaran kepada peserta didik.

\section{Guru Sebagai Pembimbing}

Tugas dan peran guru sebagai pembimbing tidak ubahnya seperti pembimbing dalam sebuah perjalanan yang mana harus berdasarkan pengetahuan dan pengalaman serta memiiki tanggungjawab demi kelancaran dalam perjalanan tersebut. ${ }^{6}$ Dengan demikian, perlu dipahami bahwa perjalanan disini tidak selalu identik dengan perjalanan secara fisik akan tetapi juga perjalanan mental, kreativitas, moral dan spiritual yang lebih bermakna. Guru sebagai pembimbing perjalanan, maka seorang guru harus memiliki empat kompetensi dalam melakukan perannya sebagai pembimbing. Pertama, ialah kompetensi dalam merencanakan, guru harus mempunyai target yang harus diperoleh sesuai dengan komptensi yang ingin dicapai. Kedua, kompetensi dalam melaksanakan pembelajaran, guru harus melihat serta mengawasikegiatan belajar mengajar peserta didik dalam pembelajaran baik secara jasmani

\footnotetext{
${ }^{5}$ Muhaimin, Nuansa Baru Pendidikan Islam, (Jakarta: PT. Raja Grafindo Persada, 2006), 168.

${ }^{6}$ Abuddin Nata, Manajemen Pendidikan, (Jakarta: Kencana Prenada Media, 2007), 23.
}

maupun secara psikologis. Ketiga, kompetensi dalam kemampuan menggunakan media dan metode pembelajaran, guru harus mempu menciptakan pembelajaran yang aktif, efeisen dan mnyenangkan dengan berbagai media dan metode yang bervariasi. Adapun yang terakhir ialah kompetensi dalam mengevaluasi, guru harus melaksanakan penilaian untuk mengetahui sejauh mana keberhasilan dalam kegiatan belajar mengajar.

\section{Guru sebagai Pemimpin}

Tugas dan peran guru sebagai pemimpin adalah bagaimana seorang guru mempunyai keperibadian yang unggul, memilki kecakapan serta memiliki kemampuan dalam mempengaruhi peserta didik agar peserta didik bisa semangat dan aktif di dalam kegiatan belajar mengajar. Guru sebagai pemimpin dalam pendidikan adalah merupakan sebuah proses yang terjadi dimana antara suatu individu (guru) memberikan pengaruh terhadap sekolompok individu lainnya (siswa) guna tercapainya tujuan pendidikan secara bersamaan. ${ }^{7}$

Kehadiran guru sebagai pemimpin di kelas diharapkan mampu memberikan dampak yang positif terhadap perkembangan peserta didik dalam kegiatan belajar-mengajar dengan ditandai adanya prestasi hasil belajar peserta didik. Oleh karena itu, guru tidak henti-henti dalam memberikan motivasi dan inspirasi terhadap peserta didik agar lebih semangat dan antusias dalam belajar.

\section{Guru sebagai Model dan Teladan}

Peran guru sebagai model dan teladan bagi peserta didik dan semua orang yang menghormati, menghargai dan menganggap dia sebagai guru. ${ }^{8}$ Tidak mungkin bisa ditolak dan ditentang bahwa peran guru sebagai teladan bagi peserta didik akan menjadi suri tauladan baik bagi peserta didik atau pun bagi lingkungan di mana guru tesebut berada. Oleh karena itu, penting diperhatikan oleh guru di dalam segala aktivitasnya baik dalam gaya bicara, rutinitas bekerja, pakaian yang digunakan, interaksi

\footnotetext{
7 Arfandi, "Implementasi Model Kepemimpinan Kontingensi dalam Pengembangan Lembaga Pendidikan Islam", Jurnal Pendidikan Islam Indonesia, Vol. 4, No. 1, (Oktober, 2020), 100.

${ }^{8}$ Hadari Nawawi, Administrasi Pendidikan, Jakarta: PT Gunung Agung, 1985), 96.
} 
dengan kemanusia, gaya hidup dan cara mengambil keputusan.

Keteladanan guru akan memberikan respon yang positif bagi peserta didik, akan tetapi penting juga diperhatikan oleh para peserta didik ada keberanian di dalam mengembangkan bagaimana gaya hidup peribadinya penuh dengan bijak, setiap apapun yang terjadi baik itu sebuah kesalahan atau kebenaran harus menyadari kesalahan yang dilakukannya dan mencoba berusaha untuk tidak mengulangi kesalahan yang sama.

\section{Sebagai Anggota Masyarakat}

Kedudukan guru sebgai seorang pendidik di masyarakat benar-benar sangat dihormati dan dihargai, masyarakat tidak meragukan lagi terhadap sosok seorang guru yang memiliki kharisma dan kewibawaan yang ada pada diri seorang guru. ${ }^{9}$ Sebagai warga masyarakat tentu seorang guru harus ikut berpartisipasi dalam pembangunan segala bidang pendidikan, ekonomi dan keorganisasian di masyarakat.

Penting juga guru sebagai anggota masyarakat untuk berinteraksi sesuai dengan keilmuan, bakat dan kemampuan yang dimiliki seperti dalam kegiatan keagamaan, kepemudaan, dan kegiatan olahraga. Pergaulan guru dengan masyarakat agar tidak terlalu kaku, karena jika hubungan dan pergaulannya dengan masrakat kaku akan berdampak terhadap penerimaan masyarakat terhadap guru tersebut di dalam kehidupan masyarakat.

7. Guru sebagai administrator

Peran guru sebagai adaministrator, selain tugas dan peran guru sebagai pendidik dan juga pengajar, guru juga berperan sebagai administrator di dalam lembaga pendidikan. Salah satu perannya dalam administrator guru harus membuat Rencana Pelaksanaan Pembelajaran (RPP) di mana dalam perencenaan tersebut sudah dibuat dengan sangat sistematis dari materi yang akan di ajarkan, media yang diapakai dan metode pelajaran.

\footnotetext{
9 Arfandi, "Perspektif Islam Tentang Kedudukan dan Peranan Guru dalam Pendidikan" Jurnal Pendidikan, Komunikasi, dan Pemikiran Hukum Islam, Vol. 11, No. 2, (April, 2020), 348-365.
}

Selain membuat rencana Pelaksnaan Pembelajaran (RPP) guru juga dituntut untuk membuat dan mencatat hasil belajar peserta didik karena itu merupakan komponen penting yang harus terdokumentasi oleh guru sebagai bukti bahwa guru tresebut sudah melaksankan tugasnya sebagai pendidik dan pengajar.

\section{Guru sebagai Pendorong Kreativitas}

Untuk menjadikan kegitan belajar mengajar penuh dengan makna, maka kehadiran guru dipandang penting untuk menjadi pendorong kreativitas terhadap peserta didik. Kegiatan belajar mengajar akan menjadi lebih efektif dan efesien ketika guru mampu untuk mendemontrasikan dan menunjukkan kreativitas tersebut dengan baik. Adanya suatu kreativitas ditandai oleh salah satu kegiatan menciptakan sesuatu yang mana pada sebelumnya tidak ada yang melakukannya.

Salah satu dampak positif dari adanya kreativitas dalam kegiatan belajar mengajar terhadap peserta didik guru senantiasa mengupayakan dalam menemukan cara yang lebih baik untuk meningkatkan pelayanan terhadap peserta didik, sehingga peserta didik tentu akan memberikan penilaian kapada gurunya bahwa ia memiliki kreativitas. Oleh karena itu, adanya kreativitas menandakan bahwa apa pun yang akan dilakukan oleh guru sekarang akan menjadikan lebih baik dari pada yang telah dilakukan oleh guru sebelumnya. ${ }^{10}$

\section{Guru sebagai Evaluator}

Tugas dan peran guru dalam memberikan evaluasi terhadap aspek pembelajaran meruapakan salah satu instrumen untuk mengetahui sejauh mana dalam kegiatan belajar mengajar peserta didik berhasil dalam belajar dalam memahami materi yang diajarkan oleh guru.

Penilaian atau evaluasi merupakan salah satu komponen terpenting dalam pembelajaran yang sangat kompleks, oleh karena itu adanya evaluasi banyak dilatar belakangi oleh beberapa variabel lain yang menunjukkan arti apabila berhubungan dengan konteks yang hampir mirip maka tidak akan mungkin

\footnotetext{
${ }^{10}$ Soebagio Atmodiwirio, Manajemen Pendidikan Indonesia, (Jakarta: Ardadizya Jaya, 2000), 11.
} 
dipisahkan dengan aspek penilaian. Oleh karena itu, menggunakan teknik apa saja yang menjadi rujukan dalam penilaian tentu harus sesuai dengan prosedur yang ada dan jelas, yang meliputi tiga tahap, yaitu persiapan dalam penilaian, pelaksanaan penilaian dan tindak lanjut dalam penilaian. ${ }^{11}$

\section{Guru Profesional sebagai Fasilitator}

Guru profesional sebagai fasilitator adalah guru yang memiliki fungsi untuk memberikan pelayanan akademik berupa fasilitas-fasilitas yang sangat dibutuhkan dalam pendidikan dan kegiatan belajar mengajar. Guru dengan fungsinnya sebagai fasilitator, maka guru akan melakukan lebih banyak waktu untuk shering dengan peserta didik dalam kegiatan belajar mengajar. Di saat guru menjelaskan tentang kompetensi dasar pada sebuah materi pelajaran yang akan diajarkan, maka guru itu tidak akan melakukan eksplorasi terhadap pelajaran tersebut, guru hanya bisa mencoba memberikan stimulasi agar peserta didik yang memiliki pengetahuan tersebut bisa menjelaskan materi pelajaran yang diajarkan oleh guru.

Sebagimana dijelaskan oleh Wina Senjaya bahwa guru sebagai fasilitator, maka guru akan memberikan pelayanan yang bertujuan untuk memberikan kemudahan terhadap peserta didik dalam melaksanakan kegiatan belajar mengajar. ${ }^{12}$ Dengan peran guru sebagai fasilitator akan membawa dampak yang positif terhadap peserta didik yang mana pada awalnya komunikasi atau hubungan antara guru dan peseta didik yang bersifat top-down maka akan berubah kepada hubungan yang bersifat kemitraan. Hubungan guru dan peserta didik yang bersifat atasan dan bawahan (top-down) cendurung guru akan bersifat otoriter terhadap peserta didik, sedangkan peserta didik yang bersifat bawahan akan selalu mengikuti terhadap segala instruksi yang diberikan oleh guru.

Hubungan guru dan peserta didik yang bersifat kemitraan tentu sangat berbeda dengan sifat guru sebagai atasan. Hubungan kemitraan guru dengan peserta didik, maka guru akan bertindak

\footnotetext{
${ }^{11}$ Abuddin Nata, Manajemen Pendidikan, (Jakarta: Kencana Prenada Media, 2007), 196.

${ }^{12}$ Wina Sanjaya, Stretegi Pembelajaran Berorientasi Standar Proses Pendidikan, (Jakarta: Prenada Media, 2008), 56.
}

sebagai pembimbing dan pendamping dalam segala aktivitas kegiatan belajar mengajar, hal ini akan menjadikan susuana pembelajaran bagi peserta didik akan menyenangkan dan demokratis.

Ada beberapa prinsip dalam kegiatan belajar mengajar yang harus dikembangkan dalam pendidikan kemitraan oleh guru yang sebgai fasilitator, oleh karena itu peserta didik dalam kegiatan belajar mengajar akan menjadi baik apabila setiap aktivitas pembelajaran peseta didik secara penuh dapat mengambil bagian, materi yang dipelajari harus bisa bermanfaat baik secara teoritis dan secra peraktis, peserta didik memiilki kesempatan untuk mengembangkan pengetahuan dan keterampilannya, materi pelajaran hendaknya harus ada relevansi dengan pengetahuan dan pengalaman peserta didik sebelumnya, serta membina hubungan baik dan saling pengertian antara guru dan peserta didik.

Selain itu pula guru seharusnya dapat memperhatikan karakteristik-karakteristik peserta didik yang tentu nantinya akan menentukan keberhasilan dalam kegitan belajar mengajar yaitu peserta didik yang satu dengan yang lainnya memiliki perbedaan baik dalam pengalaman dan potensi belajar, peserta didik memilki memiliki tendensi untuk menentukan kehidupannnya sendiri, peserta didik lebih dalam memberikan perhatian terhadap hal-hal yang sangat menarik bagi dirinya dan menjadi kebutuhan dalam hidupnya, peserta didik lebih suka terhadap hal-hal yang bersifat konkret dan praktis, peserta didik lebih senang terhadap sebuah penghargaan (reward) dari pada sebuah hukuman (punishment).

Untuk mengoptimalkan peran guru sebagai fasilitator, maka ada beberapa hal yang perlu dipahami yang berhubungan dengan cara memanfaatkan dan menggunakan berbagai media pembelajaran baik yang audio, visual dan audio visual dan juga sumber belajar. ${ }^{13}$ Oleh karena itu penting bagi guru untuk mewujudkan dirinya sebagai guru fasilitator, maka guru perlu untuk menyediakan berbagai sumber belajar dan media pembelajaran yang relevan dalam kegiatan belajar mengajar.

\footnotetext{
${ }^{13}$ Wina Sanjaya, Stretegi Pembelajaran Berorientasi Standar Proses Pendidikan, (Jakarta: Prenada Media, 2008), 76.
} 
Ada beberapa hal yang perlu diperhatikan oleh guru untuk menjadi seorang fasilitator yang sukses antara lain adalah sebagai berikut:

1. Guru harus sabar dalam menghadapi berbagai karakter peserta didik salah satunya proses pembelajaran yang dilakukan secara mandiri. Oleh karena itu, guru harus sabar ketika menemukan beberapa hambatan dan kendala dalam kegiatan belajar mengajar yang dihadapi oleh peserta didik.

2. Guru harus menghargai dan rendah hati dalam mengahdapi peserta didik. Salah satu upaya yang dilakukan guru dalam menghargai peserta didik dengan cara menunjukkan minat yang sangat sungguh-sungguh terhadap peserta didik yang memiliki potensi pengetahuan dan pengalaman.

3. Guru harus bisa memahami karakter dan potensi yang dimiliki oleh peserta didik dengan memahami potensi dan karakter dari peseta didik akan memudahkan guru dalam berinteraksi dan berkomunikasi dengan pesarta didik. Karakter itu akan membentuk motivasi, yang dibentuk dengan metode dan proses yang bermartabat. Karakter bukan hanya penampilan lahiriah, melainkan mengungkapkan secara implisit hal-hal yang tersembunyi. ${ }^{14}$ Dengan memahmi berbagai karakter dari peserta didik maka akan memudahkan guru di dalam memilih media dan metode pembelajaran yang sesuai dengan keinginan dari peserta didik.

4. Guru harus bisa dekat dan akrab dengan peserta didik. Dalam menjalin dan menjaga hubungan yang harmonis sebaiknya dilakukan dengan penuh keakraban, tenang, nyaman dan penuh cinta dan kasih sayang (interpersonal realtionship), dengan demikian, peserta didik dalam berhubungan dengan gurunya merasa nyaman dan tidak merasa sungkan dan kaku.

5. Guru harus bersifat kooperatif dengan peserta didik, guru tidak perlu bersikap bahwa dirinya yang paling pinter, paling tahu dan paling berpengalaman, akan tetapi bagaimana guru bisa

${ }^{14}$ Arfandi, "Internalisasi Pendidikan Karakter di Sekolah", Jurnal Lisan Hal, Vol. 8, No. 2, (Desember 2016), 268. bersikap kooperatif untuk saling berbagi baik dalam pengetahuan dan pengalaman terhadap peserta didik. Dengan demikian sikap yang saling pengertian ini akan memberikan dampak yang positif dalam kegitan belajar mengajar yang pada akhirnya akan berdampak terhapadap keberhasilan peserta didik dalam belajar.

6. Guru harus memiliki kewibawaan. Walaupun kegiatan belajar mengajar dilaksanakan dengan penuh suasana keakraban dan santai, guru sebagai fasilitator agar supaya tetap menunjukkan komitmen yang tinggi di dalam memberikan pembelajaran terhadap peserta didik, dengan demikian, peserta didik akan tetap menjaga hubungan yang harmonis serta menghargai keberadaan gurunya yang menjadi panutan.

7. Guru tidak memihak terhadap peserta didik, peserta didik yang merupakan tanggung jawab dari guru, tentu guru dalam memperlakukan peserta didik dengan sama. Bila mana dalam kegiatan belajar mengajar antar peserta didik terjadi perbedaan pendapat dan pertentangan, maka diharapkan kehadiran guru mampu untuk meredam segala perbedaan pendapat dan guru agar bisa menjadi mediasi di antara peserta didik tersebut untuk menemukan dan memastikan untuk berdamai dan menemukan kesepakatan dan menukan jalan keluar dari hal-hal yang menjadi perbedaan pendapat di antara mereka.

8. Guru memiliki sikap terbuka terhadap peserta didik. Keterbukaan dari seorang guru akan menjadikan peserta didik semakin semangat dalam mengikuti kegiatan belajar mengajar dan juga meambah rasa percaya terhadap gurunya. Dengan demikian, guru diharapkan tidak segansegan dalam menunjukkan keterbukaan terhadap peserta didik dan berterus terang bila mana ada hal-hal yang belum dipahami dan diketahui oleh peserta didik, oleh karena itu, peserta didik akan tetap konsisten belajar dan semangat dalam mengikuti kegiatan belajar mengajar.

9. Guru selalu berpenampilan energik dan bersikap positif. Seorang guru secara terbuka dan transparan berkomunikasi dengan peserta didik dan mengajak mereka untuk mamahami dan mengetahui tentang keberadaan dirinya yang 
sebenarnya dengan menonjolkan sikap dan sifat yang positif dan potensi-potensi yang dimiliki oleh guru tersebut, dan tidak diperkenankan bagi guru untuk menampilkan sikap-sikap yang negatif dan berkeluh kesah terhadap dirinya. Hal-hal yang menyangkut sikap positif perlu untuk diperhatikan oleh setiap guru profesional agar peran-peran guru profesional sebagai fasilitator bisa berjalan dengan baik dan bijaksana.

\section{Guru Profesional sebagai Komunitator}

Guru profesional dalam kegiatan belajar mengajar berperan penting sebagai komunikator. Pengertian komunikator secara etimologi berasaldari bahasa Inggris yaitu communication, sedangkan pengertian komunikasi secara terminologi memiliki pengetian menyampaikan sebuah pesan atau informasi, yang meliputi perasaan, pikiran, gagasan, keahlian dari komunikator kepada komunikan untuk memberikan pengaruh terhadap pikiran komunikan sebagai feedback atau tanggapan balik bagi seorang komunikator. Oleh karena itu, komunikator bisa mengukur keberhasilan dan tidaknya tentang sebuah informai atau pesan yang sudah di sampaikan kepada komunikan.

Komunikasi sebagai salah satu tempat yang strategis keberadaannya di dalam kegiatan belajar mengajar dan pendidikan. Pendidikan adalah komunikasi, karena dalam peroses pendidikan mempunyai beberapa komponen komunikator, komponen komunikan, dan komponen pesan (message). ${ }^{15}$ Pendidikan bisa dipahami dengan sebuah komunikasi karena adanya keterlibatan dua komponen penting yang terdiri dari seorang guru sebagai komonikator dan pserta didik sebagai komunikan. Dengan demikian, kegiatan belajar mengajar atau pendidikan jika dilakukan dengan proses yang komuniktif, maka pendidikan akan mencapai tujuan yang efektif dan efesien.

Interaksi antara guru dan peserta didik di kelas merupakan komunikasi kelompok dan pada saat tertentu nanti guru akan mengubah komunikasi kelompok itu menjadi komunikasi

\footnotetext{
${ }^{15}$ Arfandi, "Pemanfaatan Media Pembelajaran dalam Meningkatkan Kualitas Pembelajaran PAI di Sekolah”, Edupedia: Jurnal Studi Pendidikan dan Pedagogi Islam, Vol. 5, No. I (Juli, 2020), 70.
}

antar personal. Kegiatan belajar mengajar slah satu kegiatan yang di dalamnya ada keterlibatan seseorang dalam mendapatkan ilmu pengetahuan, skill, keterampilan dan nilai-nilai yang positif dengan menggunakan berbagai sumber untuk dijadikan belajar, dengan demikian kegiatan belajar mengajar terjadi interaksi antara dua pihak yang mana peserta didik sebagai pembelajar sedangkan guru adalah sebagai komunitator.

Komunikasi dalam kegiatan belajar mengajar memiliki peran yang sangat urgen dalam kelas, peran yang urgen itu adalah memberikan kefektifan dan kefesienan dalam kegitan belajar mengajar. Agar peran guru sebagai komunikator dapat terealisasi dengan baik, maka terdapat tiga kemampuan yang sangat esensial yang tentunya harus dilaksanakan oleh guru antara lain adalah sebagai berikut :

1. Kemampuan guru di dalam merencanakan kegiatan belajar mengajar

2. Kemampuan guru di dalam melaksanakan kegiatan belajar mengajar, dan

3. kemampuan guru dalam menciptakan iklim yang komunikatif.

Tiga kemampuan yang dimiliki guru tersebut di atas sering disebut sebagai generic essensial, dari tiga kemampuan tersebut sama-sama urgen, karena bagi setiap guru yang terpenting tidak hanya mempunyai kemampuan merencanakan sesuai rancangan saja, akan tetapi guru juga harus memiliki kemampuan dalam keterampilan pelaksanaan kegiatan belajar mengajar dan guru juga mempunyai kemapuan dalam menciptakan iklim yang komunikatif dalam kegiatan belajar mengajar.

Berlangsungnya kegiatan belajar mengajar yang efektif dan efesien tentu tidak bisa dilepaskan dari peran guru yang mempunyai kemampuan di dalam menciptakan iklim yang komunikatif, karena iklim yang komunikatif yang baik dalam hubungan secara interpersonal antara guru dengan guru yang lain, guru dengan peserta didik, dan peserta didik dengan peserta didik. Dengan demikian, kegiatan belajar mengajar di dalam kelas akan sesuai dengan kemampuan yang dimiliki oleh masing-masing. Sebab demikian akan muncul situasi sosial yang 
menyenangkan, dan emosional yang menyenangkan pada tiap personal, baik guru maupun peserta didik dalam melaksanakan tugas dan tanggung jawab masing-masing.

Peran guru dalam kegiatan belajar mengajar untuk menciptakan suasana iklim komunikatif yang kondusif, maka seyogianya guru memperlakukan peserta didik sebagai individu yang berbeda-beda, yang tentunya membutuhkan terhadap layananlayanan yang berbeda pula sesuai dengan karakteristik yang dimilki oleh peserta didik yang unik, karena peserta didik satu sama lain memiliki kamampuan yang berbeda baik tentang minat belajar, cara belajar, kecerdasan. Dengan demikian peserta didik membutuhkan kebebasan dalam menentukan pilihannya yang disesuaikan dengan kemampuan pribadinya yang aktif.

Interaksi peserta didik dalam kegiatan belajar mengajar tentu hal ini juga ada hubungannya dengan komunikasi antara peserta didik. Oleh karena itu, peran guru dalam mengelola interaksi peserta didik, usaha guru di dalam menangani berbagai kesulitan peserta didik yang sangat menganggu serta dalam mempertahankan sikap dan tingkah laku peserta didik yang positif. Agar peserta didik ikut berpartisipasi dan berinteraksi secara efektif, tentu kahadiran guru dalam mnegelola interaksi tidak hanya terfokus satua arah yaitu hanya guru dan peserta didik saja atau dua arah antara guru ke peserta didik, dari peserta ke guru, akan tetapi bagaimana interaksi itu terbangun interkasi multi arah yaitu dari guru ke peserta didik, dari peserta didik ke guru dan dari peserta didik ke peserta didik lainnya. Oleh karena itu, dari berbagai kemampuan dari guru tesebut sudah mengarah terhadap penciptaan iklim komunikatif yang merupakan wahana atau sarana bagi tercapainya tujuan pembelajaran yang optimal dan kondusif.

Agar materi pelajaran dalam kegiatan belajar mengajar disajikan lebih komunikatif, maka komunikasi materi pelajaran tentu tidak hanya dalam konteks di dalam kelas semata, akan tetapi bisa dirancang untuk di luar kelas, baik berupa tugas yang terkontrol dan tugas yang terukur, baik materi yang bersifat teoritis maupun yang bersifat praksis. Kegiatan belajar mengajar di kelas seorang guru menjelaskan materi pelajaran, perseta didik menyimak dengan baik, peserta didik bertanya, dan sebaliknya guru memperoleh berbagai informasi dari para peserta didik dan guru menjawab pertanyaan peserta didik dan secara bersama-sama antara guru dan peserta didik mencari soulusi memecahkan sebuah permasalahan yang ada. Oleh karena itu, kedua belah pihak antara guru dan peserta didik (komunikatorkomunikan) sama-sama aktif, dan peran yang lebih dominan terletak pada peserta didik yang lebih aktif. Pada akhir dari penyajian materi pelajaran, guru melakukan evaluasi untuk mengukur kemampuan siswa terhadap materi yang telah dikomunikasikan.

\section{SIMPULAN}

Guru profesional adalah suatu pekerjaan yang bersifat profesional yangmemerlukan beberapa bidang ilmu yang secara sengaja harus ditekuni dan dipelajari kemudian ilmu itu bisa diaplikasikan. Selain itu guru yang profsional harus mempunyai komptensi khusus dalam bidang keguruan sehingga ia mampu menjalankan tugas dan fungsinya sebagai guru dengan memiliki kemampuan yang maksimal. Guru sebagai fasilitator akan memberikan pelayanan yang baik dengan tujuan untuk memberikankemudahan terhadap peserta didik dalam kegiatan belajar mengajar, untuk mewujudkan guru sebagai fasilitator, maka guru perlu untuk menyediakan berbagai sumber belajar dan media pembelajaran yang relevan serta menjadikan pembelajaran yang aktif, inovatif, kreatif dan menyenangkan. Sedangkan guru sebagai komunikator dalam kegiatan belajar mengajar adalah bagaimana hubungan guru dengan peserta didik tidak bersifat "top-down" melainkan bersifat kemitraan, dengan kemitraan inilah guru akan berperan sebagai pembimbing dan pendamping dalam segala aktivitas kegiatan belajar mengajar dan hal ini akan menjadikan susuana pembelajaran bagi peserta didik menyenangkan dan demokratis karena dengan menciptakan iklim komunikatif merupakan wahana atau sarana untuk mencapai tujuan pembelajaran yang efektif dan efesien.

\section{DAFTAR RUJUKAN}

Nata, Abuddin. Manajemen Pendidikan. Jakarta: Kencana Prenada Media, 2007.

Arfandi, "Implementasi Model Kepemimpinan 
Kontingensi dalam Pengembangan Lembaga Pendidikan Islam", Jurnal Pendidikan Islam Indonesia, Vol. 4, No. 1, (Oktober, 2020)

Arfandi, "Internalisasi Pendidikan Karakter di Sekolah", Jurnal Lisan Hal, Vol. 8, No. 2, (Desember 2016).

Arfandi, "Pemanfaatan Media Pembelajaran dalam Meningkatkan Kualitas Pembelajaran PAI di Sekolah", Edupedia: Jurnal Studi Pendidikan dan Pedagogi Islam, Vol. 5, No. I (Juli, 2020).

Arfandi, "Perspektif Islam Tentang Kedudukan dan Peranan Guru dalam Pendidikan" Jurnal Pendidikan, Komunikasi, dan Pemikiran Hukum Islam, Vol. 11, No. 2, (April, 2020).

Nawawi, Hadari. Administrasi Pendidikan. Jakarta: PT Gunung Agung, 1985.

Kunandar, Guru Profesional Implementa I Kurikulum Tingkeat Satuan Pendidikandan Sukses dalam Sertifikasi Guru. Jakarta: Raja Grafindo Persada, 2007.

Usma, Moh., User. Menjadi Guru Profesional. Bandung: PT. Remaja Rosdakarya, 2010.

Muhaimin, Nuansa Baru Pendidikan Islam. Jakarta: PT. Raja Grafindo Persada, 2006.

Atmodiwirio, Soebagio. Manajemen Pendidikan Indonesia. Jakarta: Ardadizya Jaya, 2000.

Sanjaya, Wina. Stretegi Pembelajaran Berorientasi Standar Proses Pendidikan. Jakarta: Prenada Media, 2008. 